\title{
PRÁVA A ZODPOVEDNOSŤ
}

\author{
Libuša Radková $^{1}$, Mária Gažiová ${ }^{1}$, Marta Vaverčáková $^{2}$ \\ ${ }^{1}$ Trnavská univerzita, Fakulta zdravotníctva a sociálnej práce \\ ${ }^{2}$ Vysoká škola zdravotníctva a sociálnej práce sv. Alžbety, n. o., Bratislava
}

IX: 1 - 211, 2007

ISSN 1212-4117

V súčasnej dobe možno považovat' výrazný a trvalý nárast výdavkov na zdravotnícku starostlivost' za celosvetový fenomén. Určite sa bude lísit' tento nárast $\mathrm{v}$ jednotlivých štátoch podl'a ich ekonomických možností, politického systému a zdravotnej politiky, avšak nárast výdavkov je realitou, o ktorej treba uvažovat' a s ktorou je treba počítat'.

V týchto súvislostiach neprekvapuje, že o medicíne a jej využití v zdravotníckej starostlivosti sa diskutuje čoraz častejšie a do týchto diskusií vstupuje i filozofia medicíny a medicínska etika. Pretože ide o vel'mi citlivú oblast' financií, je táto otázka zaujímavá i pre zdravotné poist'ovne a veposlednej miere zaujíma i politikov.

Medzi najčastejšie obranné reakcie súčasného človeka patrí i lakonická odpoved’: „Mám na to právo", a to bez toho, či je to opodstatnené, alebo nie. L'udia si zvykli za svoje problémy robit' zodpovedným niekoho iného, nie seba.

Otázka práv sa po páde totalitného komunistického režimu dostala do popredia záujmu spoločnosti i jednotlivcov. Bolo prirodzené, že ludia zvlášt' oceňovali slobodu prejavu, zhromažd’ovania sa, pohybu, náboženskú a iné, ktoré boli v minulosti v rôznom rozsahu obmedzované, alebo dokonca i priamo potlačované. Začalo sa čoraz častejšie hovorit' o Všeobecnej deklarácii ludských práv, ktoré prijalo Valné zhromaž-denie Spojených národov v New Yorku ešte $\mathrm{v}$ roku 1947, ale o ktorom naša verejnost' nevedela a tí, ktorí túto deklaráciu verejne pripomínali, boli starým režimom kritizovaní a trestaní ako nepriatelia socializmu a pracujúceho l'udu.

Otázky slobody a l'udských práv sa potom rozpracovávali i cez d’alšie inštitúcie, ako je Rada Európy, Svetová zdravotnícka organizácia a d'alšie. Medzi významné dokumenty patrili napr. Deklarácia práv diet'at'a.

Zdravie vždy patrilo $\mathrm{k}$ vel'mi významným hodnotám človeka v každej historickej epoche a v každej spoločnosti. O zachovanie zdravia sa vždy staral človek sám, jeho rodina a najbližší príbuzní a zdravotné služby jednak zabezpečoval štát, súkromný zdravotnícky sektor, ale o zdravotnú osvetu sa starali tiež i dobrovol'nícke organizácie, ako bol Červený kríž, školy a mnoho dobrovol'ných pracovníkov, či už z radov lekárov, kňazov, domácich liečitel’ov a osvetu šíriacich inštitúcií a jednotlivcov. Treba pritom spomenút' napr. i spolky proti alkoholizmu a iné.

Vývoj ludských práv potom pokračoval d'alej a smeroval $\mathrm{k}$ definovaniu práv osobitných skupín obyvatel'stva, medzi ktoré patria i práva pacientov. Nie je našim ciel'om analyzovat' práva pacientov, ale skôr tieto práva konfrontovat' s osobnou zodpovednost'ou každého za svoje zdravie.

Zdravotná situácia obyvatel'stva sa za posledných 100 rokov výrazne zlepšovala. Na tomto skvalitňovaní zdravia sa zúčastňovali mnohé vplyvy, ako je zlepšené stravovanie obyvatel'stva, zásobovanie vodou, bývanie l’udí, vyššia vzdelanost' celých generácií, ale i dostupnost' zdravotníckej starostlivosti.

Znížila sa podstatne dojčenská úmrtnost', predlžuje sa l’udský vek, liečia sa mnohé choroby spôsobmi, o akých sa minulým generáciám ani nesnívalo. Spomeňme len pokroky $\mathrm{v}$ resuscitácii, intenzívnu starostlivost', transplantáciu orgánov, dialýzu, čiastočnú eradikáciu a úspešnú liečbu infekčných chorôb a pod.

Súčasne sa však stále objavujú nové problémy súvisiace s civilizačnými vplyvmi, s nárastom chronických chorôb, alergickými chorobami, úrazmi, nádorovými ochoreniami, HIV infekciou a AIDS chorobou a najmä s predlžovaním ludského života a mnohé d'alšie.

Zdravotnícka starostlivost' je stále nákladnejšia a ani najbohatšie štáty nie sú schopné zabezpečit' zdravotnícku starostlivost' na žiadúcej úrovni. A tak sa otázky práv pacientov stále častejšie konfrontujú so zodpovednost'ou kaž- 
dého za svoje zdravie. Otázky zodpoved-nosti majú svoje i objektívne odôvodnenie. L'udia, ale i zdravotné poist'ovne sa pýtajú, či človek, ktorý si vedome poškodzuje svoje zdravie, bude mat' rovnaké nároky na zdravotné služby ako ten, čo svojou životosprávou sa o svoje zdravie skutočne stará. Teda už nie lekár, sestra, zdravotná poist'ovňa, rezort zdravotníctva, nemocnica, zdravotné ústavy a teda $\mathrm{v}$ konečnom dôsledku štát sú zodpovedné za zdravie jednotlivca, ale $\mathrm{v}$ prvom rade človek sám. To však v žiadnom prípade neznamená povinnost’ štátu a jeho inštitúcií zabezpečovat' zdravé životné a pracovné podmienky pre svojich občanov, dostupné zdravotnícke služby, rôzne preventívne opatre-nia, hygienický dohl'ad, osvetu a pod.

Pre zdravotníkov však eticky vyplýva, že nebudú sudcami toho, že alkoholik je zodpovedný za svoju cirhózu pečene, fajčiar za svoj karcinóm plúc, homosexuál za svoju HIV infekciu a pod. Ich povinnost'ou je zdravotné služby poskytovat' tým, ktorí to potrebujú. Potom by ret’az obvinení pokračovala, že niekto sa ponáhl'al a padol dole schodmi, pričom si zlomil nohu, horolezec padol zo skaly, chodec vstúpil do jazdnej dráhy auta a nekonečné množstvo eventualít, kde by sa mohla dedukovat' zodpovednost' jednotlivca. Tu je problém nie v rovine osobnej zodpovednosti za svoje zdravie a jeho ochranu.

V našom príspevku sme chceli stručne poukázat' na dilemy zodpovednosti a práva na zdravie, v širšom rozsahu ako sa bežne uvažuje. Ide vlastne o základnú dilemu slobody človeka a jeho zodpovednosti, ktorá sprevádza súčasného človeka. Sloboda bez zodpovednosti môže byt' v čisto osobnej interpretácii zneužívaná na škodu spoločnosti i jednotlivca. I práva pacientov, tak humánne a eticky definované, sú bez zodpovednosti človeka za svoje zdravie len prázdnym dokumentom, ba dokonca zdrojom konfliktov pri neprimeraných, nekritických nárokoch tých, u ktorých absentuje osobná zodpovednost' za svoje zdravie alebo za zdravie tých, ktorí sú mu zverení.

Záverom si treba položit' niektoré otázky do diskusie: Je spravodlivé, aby tí, ktorí zdravo žijú, museli platit' na výdaje zdravotnej starostlivosti za tých, ktorí tak nežijú? Mali by tí, ktorí nežijú zdravo, byt' nejakým spôsobom postihnutí a teda sankcionovaní? Mali by tí, ktorí si svoje zdravie poškodzujú, platit' vyššie nemocenské poistenie? V akej výhode sú, alebo nie sú v požiadavkách na zdravotnícku starostlivost' tí, ktorí žijú zdravo, nefajčia, nepijú, zdravo sa stravujú a zdravo si udržujú telesnú i duševnú kondíciu, pritom si doprajú primeraný oddych.

Nemáme odpovede na tieto otázky, nechceme byt' prísnymi sudcami našich pacientov, ale musíme si stavat' i nepopulárne otázky, aby sme spoločne hl'adali odpovede.

Libuša Radková, Mária Gažiová a Marta Vaverčáková lradkova@truni.sk 